\title{
BEHAVIOUR OF REINFORCED CONCRETE INFILL PANELS UNDER
}

\author{
LATERAL LOAD
}

\author{
Sandesh Sharma ${ }^{1}$, Sharadkumar Purohit ${ }^{2}$, Paresh V. Patel ${ }^{3}$, Tushar Bhoraniya ${ }^{4}$ \\ ${ }^{1}$ M. Tech. Student, Civil Engineering Department, Institute of Technology, Nirma University, Ahmedabad, India- \\ 382481,13mclc21@nirmauni.ac.in \\ ${ }^{2}$ Professor, Civil Engineering Department, Institute of Technology, Nirma University, Ahmedabad, India - 382481, \\ sharad.purohit@nirmauni.ac.in \\ ${ }^{3}$ Professor, Civil Engineering Department, Institute of Technology, Nirma University, Ahmedabad, India - 382481, \\ paresh.patel@nirmauni.ac.in \\ ${ }^{4}$ Ph. D. Student, Civil Engineering Department, Institute of Technology, Nirma University, Ahmedabad, India- \\ 382481, 12extphd90@nirmauni.ac.in
}

\begin{abstract}
Most multi-storey building construction consists of RC frames with UM infills. Traditionally, infills are made of the RCB; however, to reduce Dead Load on the building, RCB are being replaced by AAC and FAB. UM infill is vulnerable element during an earthquake, since it fails by Shear, Sliding and Out-of-plane bending. Behaviour of infill with RCB is well studied; however, studies on infill with AAC and FAB are limited. In the present study, behaviour of different RC infill panels is studied and compared with bare RC frame under monotoniclateral load. RC frame specimens comprising of two columns connected by horizontal beam at top and bottom are developed and tested. Parameters considered for the study are Lateral Displacement, Lateral Stiffness, Failure Load and Patterns. Lateral displacement of all types of RC infill panels are reduced substantially as compared to bare RC frame. RC frame infilled with AAC block shows maximum lateral displacement followed by RC frame infilled with FAB and RCB. RC frame infilled with RCB withstand maximum lateral load while RC frame infilled with FAB withstandthe least load. The failure patterns observed for RC frame with different infills are mostly stepped type and shear type.
\end{abstract}

\section{KEYWORDS: Prism Test, AAC Block, Fly Ash Brick, R.C. Infilled Frame, Monotonic Lateral Load}

\section{INTRODUCTION}

Use of masonry panels in RC frame buildings is very common in developing countries to serve various purposes. Most commonly used material is Red Clay Brick due economy. An infilled RC frame panels behaves as composite structure under lateral load. Current construction practice undertakes extended use of light-weight infill panel elements as compared to relatively heavy RCB in order to reduce the Dead Load on the building. This is typically followed for moderate- to high rise buildings. The infill panels are one of the vulnerable elements in the RC building when subjected to earthquake excitation. Therefore, it is important to study the behaviour of infill panels under lateral load.Behaviour of RC infill panels with RCB are well studied by many researchers, however, studies on RC frame infilled with AAC and FAB is limited. Therefore, it is imperative to study the influence of such infill panels to earthquake excitation.

Present study deals with behaviour of Bare RC Frame and RC Frame infilled with RCB, AAC and FAB under monotonic lateral loads. Four RC Framespecimens are casted that included one bare $\mathrm{RC}$ frame and three $\mathrm{RC}$ frame infillswith RCB, AAC and FAB. All RC frames are tested under monotonic lateral load and parameters like lateral displacement, Lateral stiffness, Failure loads and patterns are extracted. Parameters obtained experimentally for all infilled RC frame are compared with bare RC frame as well as former are compared among themselves.

\section{LITERATURE REVIEW}

Many studies have been done on the evaluation of the mechanical properties of the infill materials as well as on the behaviour of the RC infill panels under lateral load. Sarangapaniet al. ${ }^{1}$ have studied Mortar and Compressive Strength of masonry. It has been showedthat masonry compressive strength is not affected by mortar bond strength significantly.For poor bond strength, masonry prism leads to failure throughbond separation of one or more joints. AlShebani andSinha ${ }^{2}$ studied deformation characteristics of a sand plast (a form of calcium silicate) brick masonry model subjected to uniaxial cyclic loading in both perpendicular and parallel direction of the bed joint. Failure in compression occurred by splitting in bed joints for loads parallel to the bed joint, whereas for load normal to the bed joint, failure was characterized by a combined failure in the brick units and/or head joint, often accompanied by throughsplitting in the midsection of panel. Hamid andChukwunenye ${ }^{3}$ showed thath/t ratio has a significant influence on the behaviour of masonry prisms. Study suggests that practice of concrete masonry prisms with $\mathrm{h} / \mathrm{t}=$ 2.0 and onebed joint as standard prism should be discontinued, and prisms with number of bed joints greater than or equal to two should be used to determine the 
compressive strength of concrete masonry prisms. Naraine and Sinha ${ }^{4}$ studied the stress-strain characteristics of brick masonry prisms under cyclic compressive loading.Specimens loaded perpendicular to the bed joint, the failure was characterized by splitting of the bricks in a plane parallel to the plane of the panel while specimens loaded parallel to the bed joint, the failure occurred by splitting in the vertical bed joints accompanied by some vertical cracks in the bricks.

Madan et al. ${ }^{5}$ have described the important in-plane failure modes of masonry infilled frames, which include: (1) tension failure of the tension column due to overturning moments; (2) flexural or shear failure of the columns;(3) compression failure of the diagonal strut; (4) diagonal tension cracking of the panel; and(5) sliding shear failure of the masonry along horizontal mortar beds.Asteris ${ }^{6}$ has demonstrated the influence of openings in the brick masonry infilled panels to lateral stiffness of frames using a FEM. Decrease in the lateral stiffness of infilled frame as high as $87 \%$ is achieved, with increase in openings, as compared to bare frame. The stiffness factor remains practically constant for infilled frame with openings exceeding 50\%.The overall action between the frame and the infill is adversely affected as the opening position is moved towards the compression diagonal.

\section{BEHAVIOUR OF INFILLED PANELS}

In the conventional design methodology adopted for design of Building with MR frames, the contribution of infill panels is neglected towards stiffness calculation and only mass is considered. However, extensive experimental studies indicated that infill panel undergo diagonal cracks which indicated that it attracts some amount of force and modifies the structural response of the building. Thus, it is important to consider such contribution of infill panels for the design of the building. Three potential modes of failure ${ }^{7}$ of the infill panel arise as a result of its interaction with the frame. The first is the shear failure stepping down to the joints of the masonry, and precipitated by the horizontal shear stresses in the bed joints. The second is the diagonal cracking of the panel through the masonry along a line, or lines, parallel to the leading diagonal and caused by tensile stresses perpendicular to the leading diagonal. In the third mode of the failure, a corner of the infill at one of the ends of the diagonal strut may be crushed against the frame due to high compressive stresses in the corner.

\section{PRISM TEST}

Current study includes determination of mechanical properties like Compressive Stress, Water Absorption of material as well as of prism specimens made from RCB, AAC, FAB. Mechanical properties of RCB and FAB infill materials is determined as per IS: $3495-1992^{8}$ and for AAC infill materials used is as per IS: 6441-1972\%. The mechanical properties determined for different infill panels are shown in Table 1.The compressive strength of mortar was also performed on the 36 cubesfor 1:4 cement: sand having W/C ratio of 0.85 . The average cube compressive strength of mortar obtained, as per IS: $2250-1981^{10}$, is 6.07 $\mathrm{N} / \mathrm{mm}^{2}$.

Mechanical properties like Compressive Strength, Modulus of Elasticity is determined through Prism Test as per IS: 1905-1987 ${ }^{\mathbf{1 1}}$. Prism test consists of prisms made from RCB and $\mathrm{FAB}$ in 5,6 and 7 layers while prisms of AAC Block in 3 and 4 Layers by maintaining h/t ratio between 2 to 5 . Prisms prepared from AAC Block are as shown in Figure 1. The average values of the basic Compressive Strength and Modulus of elasticity of prisms of different infill materials aretabulated in Table 2.

\section{EXPERIMENTAL TEST ON INFILL RC}

\section{FRAME}

This section includes brief description of building considered for deriving RC frame segment for the experimental testing. It also includes preparation of $\mathrm{RC}$ frame test specimens and Lateral load mechanism used in the experimental testing.

\subsection{Building Configuration}

A G+2 storey RC building of $16 \mathrm{~m} \times 16 \mathrm{~m}$ plan dimension is considered. The typical storey height considered is $3.2 \mathrm{~m}$. The plan and elevation of the building is shown in Figure 2. The loading data and material data used for the design of the $\mathrm{RC}$ building are given in Table 3. The building is designed as per IS: $456-2000^{12}$ using software STAAD.Pro ${ }^{13}$ and dimensionsfor all structural elements are derived. The infill panels of the building are modelled as a single equivalent diagonal strut carrying compressiveforce only.The width of diagonal strut is determined using Equation (1) proposed by Pauley and Preistley ${ }^{14}$.

$w=\frac{d}{4}$

\subsection{Scaled Model of RC Frame}

In order to perform experiment on RC frame, test specimen is to be derived through dimension analysis. Scale model of the $\mathrm{RC}$ building is derived by applying appropriate scale factors for Linear Dimension, Load, Moment and Pressure. The dimensions for structural elements for prototype building and $1 / 3^{\text {rd }}$ scale building are shown in Table 4 . The scaled RC frame developed for experimental testing has column size of $100 \mathrm{~mm} \times 100 \mathrm{~mm}$ and beam size of $100 \mathrm{~mm}$ $\times 150 \mathrm{~mm}$. Figure 3 shows scaled RC Frame with reinforcement. Note that, the size of beam is kept more than that of column size to ensure shear failure of the frame and no bending in the column takes place.

\subsection{Lateral Load Mechanism}

Department of Civil Engineering, Institute of technology, Nirma University has facility of Loading frame of $1000 \mathrm{kN}$ capacity. It is capable of testing scaled model of RCC elements under gravity loading; however, it has a limitation of offering lateral load to any RRC element. An 
indigenously developed lateral load mechanism is fabricated. The lateral load is applied through hydraulic jack attached to lateral load mechanism as shown in Figure4.

\subsection{Boundary Condition Simulation}

To achieve fixity at the base of RC frame, two box sections of steel plates are used. The boxes are connected to steel beam section fixed with the reaction floor.

\section{RESULTS AND DISCUSSIONS}

Result for bare RC Frame and RC frame with different infill materials is obtained in the form of Lateral Displacement, Lateral Stiffness, Failure Load and Pattern. Lateral displacement of RC frame is obtained through Mechanical Dial Gauge at top of the frame. The monotonic lateral load is applied in the increment of $5 \mathrm{kN}$ through hydraulic jack of $250 \mathrm{kN}$ capacity. The load versus lateral displacement plot for each load cycle (loading and unloading) is plotted to derive lateral stiffness and Failure Load. The complete experimental set-up with instrumentation is shown in Figure 5.

\subsection{Bare RC Frame}

Bare RC Frame when subjected to monotonic lateral load shows maximum displacement of $28.56 \mathrm{~mm}$ and maximum failure load of $50 \mathrm{kN}$. Maximum Lateral displacement and lateral stiffness of bare RC frame is tabulated in Table 5. Apart, load versus lateral displacement plot is shown in Figure 6. It is evident from Figure 6 that curve shows linear behaviour for first cycle of loading (i.e. 0-10 kN) followed by inelastic behaviour. It is also clear from Figure 6 that lateral stiffness of RC frame reduces from $3390 \mathrm{~N} / \mathrm{m}$ to 1750 $\mathrm{N} / \mathrm{m}$ after five cycle of loading and unloading.

Bare RC frame shows three different from of failure pattern under monotonic lateral load; (i) Beam - column separation at leeward (bottom side opposite to loading end) side (ii) top of horizontal beam at loading side shows tension cracks due to negative bending moment and compression cracks due to positive bending moment at the bottom of top horizontal beam at loading side (iii) shear deformation of the RC frame. Figure 7 shows the failure patterns undergone by bare RC frame.

\subsection{RBC Infilled Frame}

Unlike bare RC Frame, RC frame infilled with RBC shows reduction in Lateral Displacement and increment in Lateral Stiffness. RBC infilled frame when subjected to monotonic lateral load shows maximum lateral displacement of 5.36 $\mathrm{mm}$ and maximum failure load of $60 \mathrm{kN}$. Thus, RBC infilled panels sustain $20 \%$ higher lateral load as compared with bare RC frame. Maximum lateral displacement and lateral stiffness of RBC infilled panel is tabulated in Table 6. It is seen from the Table 6 that lateral stiffness reduces from $25000 \mathrm{~N} / \mathrm{m}$ to $11194 \mathrm{~N} / \mathrm{m}$.Lateral stiffness (initial) of RBC infilled panels shows seven times increment in lateral stiffness as compared to bare R.C. frame. Lateral load versus lateral displacement for RBC infilled panels is shown in Figure 8. It is clear from Figure 8that, curve shows linear behaviour initially, and followed by inelastic behaviour over remaining loading cycles.

$\mathrm{RC}$ frame infilled with RCB shows three different form of failure pattern under monotonic lateral load; (i) separation of mortar bond at column face (ii) stepped type of failure in RCB infill panel (iii) failure of horizontal mortar joint. Figure 9(A), (B), (C) shows the failure patterns as mentioned above undergone by RCB infilled RC frame.

\subsection{AAC Block Frame:}

AAC Block RC infilled frame shows the behaviour likely as the RC frame infilled with RCB Block. AAC block infilled frame when subjected to monotonic lateral load shows maximum lateral displacement of $5.36 \mathrm{~mm}$ and maximum failure load of $60 \mathrm{kN}$. The lateral displacement is decreased and lateral stiffness is increased as compared to the Bare RC frame. But for this RC infill frame, the lateral displacement is increased and lateral stiffness is decreased as compared with the RC Frame infilled with RCB. Lateral stiffness (initial) of AAC block infilled panels shows six times increment in lateral stiffness as compared to bare R.C. frame, however, it shows one-and-half times decrement in lateral stiffness as compared with RC frame infilled with RCB. Lateral load versus lateral displacement for AAC Block infilled panels is shown in Figure 10.It is clear from Figure 10 that linear behaviour is observed for the initial loading cycles.It is seen from Table 7 that the lateral stiffness is reduced from $19607 \mathrm{~N} / \mathrm{m}$ to $9063 \mathrm{~N} / \mathrm{m}$ after five loading/unloading cycles.

RC frame infilled with AAC Block shows three different form of failure pattern under monotonic lateral load; (i) separation of mortar bond at column face (ii) AAC Block Failure (iii) failure of horizontal mortar joint. Figure 11 (A), (B), (C) shows the failure patterns as mentioned above undergone by AAC Block infilled RC frame.

\subsection{Fly Ash Brick Frame}

RC frame infilled with FAB shows the behaviour likely as RC frame infilled RCB and AAC block. When subjected to monotonic cyclic loading, it undergoes maximum displacement of $4.95 \mathrm{~mm}$ at maximum load of $45 \mathrm{kN}$. For this RC frame, the load carrying capacity is decreased by $25 \%$ as compared with RC frame infilled with RCB and AAC block. The maximum lateral displacement for each cycle is shown in Table 8 . The (initial) lateral stiffness of frame is increased by 10 times as compared with bare RC frame. It is also observed that initially, the stiffness of the $\mathrm{RC}$ frame is greater than the RC frame infilled with $\mathrm{RCB}$ but for later cycles, the stiffness was decreased. The lateral load versus lateral displacement plot is shown in Figure 12. The lateral stiffness is decreased from $35714 \mathrm{~N} / \mathrm{m}$ to 9090 $\mathrm{N} / \mathrm{m}$ for 5 numbers of loading/unloading cycles.

$\mathrm{RC}$ frame infilled with $\mathrm{FAB}$ shows three different forms of failure pattern under monotonic lateral load; (i) separation of mortar bond at column face (ii) Stepped type failure (iii) Crushing of the FAB. Figure 13 (A), (B), (C) shows the failure patterns as mentioned above undergone by $\mathrm{FAB}$ infilled RC frame. 


\section{SUMMARY AND CONCLUSIONS}

Behaviour of bare RC Frame and RC Frame infilled with $\mathrm{RCB}, \mathrm{AAC}$ and FAB is studied under monotonic lateral load. Physical and Mechanical properties of infilled materials is determined through Prism Test. A G+2 storey $\mathrm{RC}$ building is designed using STAAD.Pro. Infill is modelled as equivalent diagonal strut for the design of the building. Single specimen of RC bare frame and three RCframes infilled with RCB, AAC and FAB is casted and tested under monotonic lateral loads. Behaviour of RC frame is obtained in the form of Lateral Displacement, Lateral Stiffness, Failure load and Patterns.

Following conclusions are derived based on experimental work carried out on RC frames.

- The Water Absorption for Fly Ash bricks is observed to be quite high as compared to RCB \& AAC Blocks, where later has the values falling within range as suggested in the literature.

The Modulus of Elasticity for the Red Bricks ranges from $150 \mathrm{~N} / \mathrm{mm} 2$ to $350 \mathrm{~N} / \mathrm{mm} 2$. The value of Modulus of Elasticity is quite low for the Fly Ash Bricks and AAC Blocks. The values range between $40 \mathrm{~N} / \mathrm{mm} 2$ to $90 \mathrm{~N} / \mathrm{mm} 2$.

- $\quad$ RC fame with RCB shows highest lateral stiffness due higher value of Modulus of Elasticity and hence, suffered least lateral displacement as compared to other infilled RC frame.

- All infilled RC frames show initially linear behaviour followed by non-linear behaviour towards failure loading. Lateral stiffness reduces by about $54 \%$ for RCB and AAC infilled RC Frames while reduction in lateral stiffness is about $74 \%$ for $\mathrm{FAB}$ infilled RC frame from initial loading to failure loading.

- $\quad \mathrm{RCB}$ and AAC block infilled RC frame withstand $20 \%$ higher lateral load as compared to bare RC Frame. However, FAB infilled RC frame shows $10 \%$ reduction in lateral load resistance as compared to bare $\mathrm{RC}$ frame this is attributed to crushing of FAB.

Failure load is maximum for RC frame infilled with $\mathrm{RCB}$ and $\mathrm{AAC}$ as compared to FAB infilled RC Frame.

- $\quad$ RC Frame infilled with RCB, AAC and FAB shows typical failure patterns like de-bonding of masonry with column face, Stepped shear failure, Horizontal joint failure. However, RC frame infilled with AAC block also shows failure of block.

\section{NOTATIONS}

AAC- Autoclaved Aerated Concrete Block

$\mathrm{d}$ - Length of the diagonal (m)

FAB- Fly Ash Brick

FEM- Finite Element Modelling

h- Height
MR- Moment Resisting

OMRF- Ordinary Moment Resisting Frame

RC- Reinforced Concrete

RCB- Red Clay Brick

t- Thickness

UM- Unreinforced Masonry

w- Width of strut (m)

W/C- Water/Cement ratio

\section{REFERENCES}

[1] Sarangapani G., Venkatarama Reddy B. V., Jagadish K. S., "Brick-Mortar Bond and Masonry Compressive Strength", Journal of Materials in Civil Engineering, ASCE,Vol. 17, No. 2, April 2005,pp. 229-237.

[2] AlShebani M.M.,Sinha S.N., "Stress-Strain Characteristics of BrickMasonry Under Uniaxial Cyclic Loading", Journal of Structural Engineering,ASCE, Vol. 125, No. 6, June 1999, pp.600-604.

[3] Hamid A. A., Chukwunenye A.O., "Compression Behaviour ofConcrete Masonry Prisms", Journal of Structural Engineering, ASCE, Vol. 112, No. 3, March 1986, pp.605-613.

[4] Naraine K.,Sinha S, "Behaviour of Brick Masonry UnderCyclic Compressive Loading", Journal of Construction Engineering and Management, ASCE, Vol. 115, No. 2, June 1989, pp.1432-1445.

[5] Mander J. B., Madan A.,Reinhorn A. M., Valles R. E., "Modelling of Masonry Infill Panels for Structural Analysis", Journalof Structural Engineering, ASCE,Vol. 123, No.10, October 1997,pp. 1298-1302.

[6] Asteris P. G., "Lateral Stiffness of Brick Masonry Infilled Plane Frames", Journal of Structural Engineering, ASCE, Vol. 129, No. 8, August 2003, pp.1071-1079.

[7] Smith B.S.,Coull A., "Tall Building Structure: Analysis and Design", Wiley India Pvt. Ltd., New Delhi, 1991.

[8] IS: 3495-1992. Indian Standard, "Methods of Tests of Burnt Clay Building Bricks."

[9] IS: 6441-1972. Indian Standard, "Method of Test for Autoclaved Cellular ConcreteProducts."

[10] IS: 2250-1981, Indian Standard, "Code of Practice for Preparation and Use of Masonry Mortar."

[11] IS: 1905-1987, Indian Standard, "Code of Practice for Structural Use of Unreinforced Masonry."

[12] IS: 456-2000, Indian Standard, "Plain and Reinforced Concrete - Code of Practice."

[13]"3D Structural Analysis \& Design Engineering Software - STAAD.Pro"

[14] Pauley T., PriestleyM.J.N., "Seismic Design of Reinforced Concrete and Masonry Building", Wiley India Pvt. Ltd., New Delhi, 1992. 


\section{TABLES}

Table 1: Mechanical Properties of Infill Materials

\begin{tabular}{|c|c|c|c|}
\hline Sr. No. & Materials & $\begin{array}{c}\text { Average Compressive Stress } \\
\left(\mathrm{N} / \mathrm{mm}^{2}\right)\end{array}$ & $\begin{array}{c}\text { Average Water Absorption } \\
(\%)\end{array}$ \\
\hline 1. & Red Bricks & 7.60 & 17.56 \\
\hline 2. & Fly Ash Bricks & 4.10 & 32.73 \\
\hline 3. & AAC Blocks & 5.94 & 6.67 \\
\hline \multicolumn{3}{|c|}{ All test were carried for 5 number of specimen for each material } \\
\hline
\end{tabular}

Table 2: Mechanical Properties of Prisms with Different Infill Materials

\begin{tabular}{|c|c|c|c|c|c|}
\hline $\begin{array}{l}\text { Sr. } \\
\text { No. }\end{array}$ & Material & $\begin{array}{l}\text { No. of } \\
\text { Layer }\end{array}$ & $\mathrm{h} / \mathrm{t}$ ratio & $\begin{array}{c}\text { Average Basic } \\
\text { Compressive Strength }\left(\mathrm{N} / \mathrm{mm}^{2}\right)\end{array}$ & $\begin{array}{c}\text { Average Modulus } \\
\text { of Elasticity } \\
\left(\mathrm{N} / \mathrm{mm}^{2}\right)\end{array}$ \\
\hline \multirow{3}{*}{1.} & \multirow{3}{*}{$\begin{array}{l}\text { Red Clay } \\
\text { Brick }\end{array}$} & 5 & 1.88 & 0.39 & 121.25 \\
\hline & & 6 & 2.29 & 0.38 & 258.16 \\
\hline & & 7 & 2.64 & 0.35 & 298.57 \\
\hline \multirow{3}{*}{2.} & \multirow{3}{*}{$\begin{array}{l}\text { Fly Ash } \\
\text { Brick }\end{array}$} & 5 & 1.80 & 0.189 & 45.79 \\
\hline & & 6 & 2.14 & 0.102 & 51.26 \\
\hline & & 7 & 2.52 & 0.204 & 78.71 \\
\hline \multirow[t]{2}{*}{3.} & \multirow{2}{*}{ AAC Block } & 3 & 1.03 & 0.267 & 42.99 \\
\hline & & 4 & 1.35 & 0.261 & 72.8 \\
\hline
\end{tabular}

Table 3: Loading and Material Data for RC Building

\begin{tabular}{|c|c|}
\hline Dead Load: & Self-Weight of structural element \\
\hline Live Load on Floor: & $2 \mathrm{kN} / \mathrm{m}^{2}$ \\
\hline Live Load on Roof: & $1 \mathrm{kN} / \mathrm{m}^{2}$ \\
\hline Floor Finish on Floor and Roof: & $1 \mathrm{kN} / \mathrm{m}^{2}$ \\
\hline Height of each Storey: & $3.2 \mathrm{~m}$ \\
\hline Wall Thickness: & Bhuj (Gujarat) \\
\hline Location of Building: & $\mathrm{V}$ \\
\hline Seismic Zone : & 1 \\
\hline Importance Factor: & 5 \\
\hline Sesponse Reduction Factor for OMRF: & Type II \\
\hline Zeta (x): & $5 \%$ \\
\hline Characteristics Strength of Concrete: & $25 \mathrm{~N} / \mathrm{mm}^{2}$ \\
\hline Yield Strength of Steel: & $415 \mathrm{~N} / \mathrm{mm}^{2}$ \\
\hline Height of Parapat: & $1.2 \mathrm{~m}$ \\
\hline
\end{tabular}


Table 4: Structural Element for Prototype and Scaled Structure

\begin{tabular}{|c|c|c|c|}
\hline Sr. No. & Element & Prototype & $1 / 3^{\text {rd }}$ Scale \\
\hline 1. & Beam Size & $300 \mathrm{~mm} \times 450 \mathrm{~mm}$ & $100 \mathrm{~mm} \times 150 \mathrm{~mm}$ \\
\hline 2. & Column Size & $300 \mathrm{~mm} \times 450 \mathrm{~mm}$ & $100 \mathrm{~mm} \times 100 \mathrm{~mm}$ \\
\hline 3. & Slab Thickness & $150 \mathrm{~mm}$ & $150 \mathrm{~mm}$ \\
\hline 4. & Length of Beam & $4 \mathrm{~m}$ & $1.33 \mathrm{~m}$ \\
\hline 5. & Height of Column & $3.2 \mathrm{~m}$ & $1.07 \mathrm{~m}$ \\
\hline 6. & Dead Load & $3.75 \mathrm{kN} / \mathrm{m}^{2}$ & $3.75 \mathrm{kN} / \mathrm{m}^{2}$ \\
\hline 7. & Live Load & $2.0 \mathrm{kN} / \mathrm{m}^{2}$ & $2.0 \mathrm{kN} / \mathrm{m}^{2}$ \\
\hline 8. & Floor Finish & $1.0 \mathrm{kN} / \mathrm{m}^{2}$ & $1.0 \mathrm{kN} / \mathrm{m}^{2}$ \\
\hline & Wall Load & & $4.90 \mathrm{kN} / \mathrm{m}$ \\
\hline \multirow{2}{*}{9.} & Outer Wall & $14.72 \mathrm{kN} / \mathrm{m}$ & $3.2 \mathrm{kN} / \mathrm{m}$ \\
\hline & Inner Wall & $9.6 \mathrm{kN} / \mathrm{m}$ & $1.84 \mathrm{kN} / \mathrm{m}$ \\
\hline & Parapet Wall & $5.52 \mathrm{kN} / \mathrm{m}$ & $0.1 \mathrm{~m}$ \\
\hline & Diagonal Strut Width & $0.3 \mathrm{~m}$ & $0.43 \mathrm{~m}$ \\
\hline 10. & Diagonal Strut Depth & $1.28 \mathrm{~m}$ & \\
\hline
\end{tabular}

Table 5: Maximum Lateral Displacement andLateral Stiffness for Bare Frame

\begin{tabular}{|c|c|c|c|}
\hline Sr No. & Loading Cycles $(\mathrm{kN})$ & $\begin{array}{c}\text { Lateral Displacement } \\
(\mathrm{mm})\end{array}$ & $\begin{array}{c}\text { Lateral Stiffness } \\
(\mathrm{N} / \mathrm{m})\end{array}$ \\
\hline 1. & $0-10$ & 2.95 & 3390 \\
\hline 2. & $0-20$ & 6.4 & 3125 \\
\hline 3. & $0-30$ & 12.89 & 2328 \\
\hline 4. & $0-40$ & 19.83 & 2017 \\
\hline 5. & $0-50$ & 28.56 & 1750 \\
\hline
\end{tabular}

Table 6: Maximum Lateral Displacement and Lateral Stiffness for RCB Frame

\begin{tabular}{|c|c|c|c|}
\hline Sr No. & Loading Cycles $(\mathrm{kN})$ & $\begin{array}{c}\text { Lateral Displacement } \\
(\mathrm{mm})\end{array}$ & $\begin{array}{c}\text { Lateral Stiffness } \\
(\mathrm{N} / \mathrm{m})\end{array}$ \\
\hline 1. & $0-10$ & 0.4 & 25000 \\
\hline 2. & $0-20$ & 0.83 & 24096 \\
\hline 3. & $0-30$ & 1.77 & 16950 \\
\hline 4. & $0-40$ & 2.67 & 14981 \\
\hline 5. & $0-50$ & 3.81 & 13124 \\
\hline 6. & $0-60$ & 5.36 & 11194 \\
\hline
\end{tabular}

Table 7: Maximum Lateral Displacement and Lateral Stiffness for AAC Block Frame

\begin{tabular}{|c|c|c|c|}
\hline Sr No. & Loading Cycles $(\mathrm{kN})$ & $\begin{array}{c}\text { Lateral Displacement } \\
(\mathrm{mm})\end{array}$ & $\begin{array}{c}\text { Lateral Stiffness } \\
(\mathrm{N} / \mathrm{m})\end{array}$ \\
\hline 1. & $0-10$ & 0.51 & 19607 \\
\hline 2. & $0-20$ & 1.21 & 16529 \\
\hline 3. & $0-30$ & 2.04 & 14705 \\
\hline 4. & $0-40$ & 3.11 & 12862 \\
\hline 5. & $0-50$ & 4.53 & 11037 \\
\hline 6. & $0-60$ & 6.62 & 9063 \\
\hline
\end{tabular}

Table 8: Maximum Lateral Displacement and Lateral Stiffness for FAB Frame

\begin{tabular}{|c|c|c|c|}
\hline Sr No. & Loading Cycles $(\mathrm{kN})$ & $\begin{array}{c}\text { Lateral Displacement } \\
(\mathrm{mm})\end{array}$ & $\begin{array}{c}\text { Lateral Stiffness } \\
(\mathrm{N} / \mathrm{m})\end{array}$ \\
\hline 1. & $0-10$ & 0.28 & 35714 \\
\hline 2. & $0-20$ & 0.95 & 21052 \\
\hline 3. & $0-30$ & 1.9 & 15790 \\
\hline 4. & $0-40$ & 3.05 & 13114 \\
\hline 5. & $0-45$ & 4.95 & 9090 \\
\hline
\end{tabular}




\section{FIGURES}

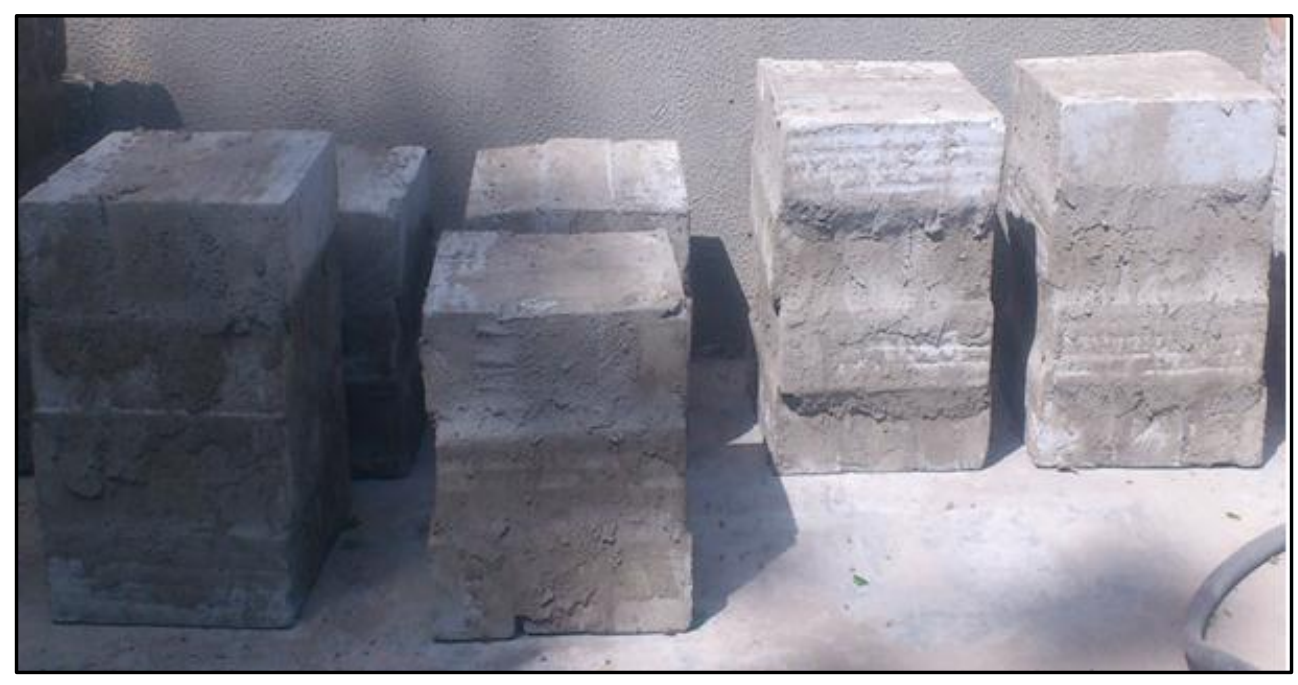

Figure 1: AAC Prism Specimen
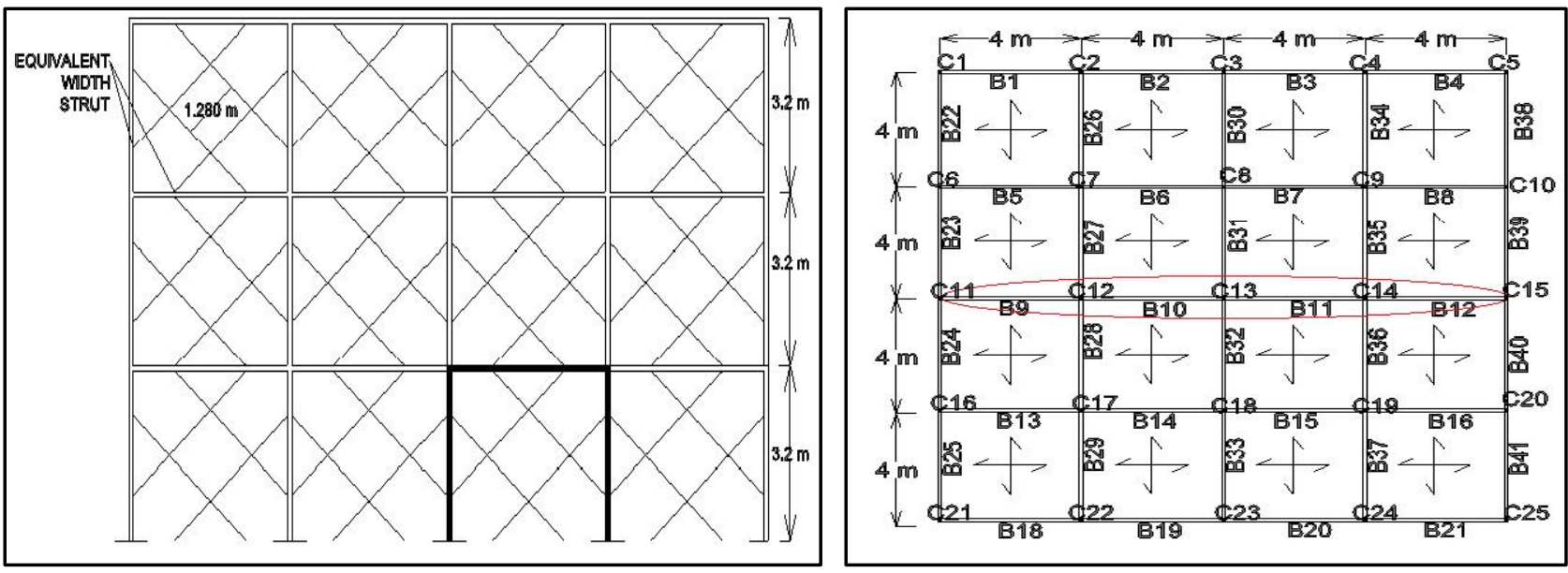

Figure 2: Plan and Elevation on the G+2 Building 


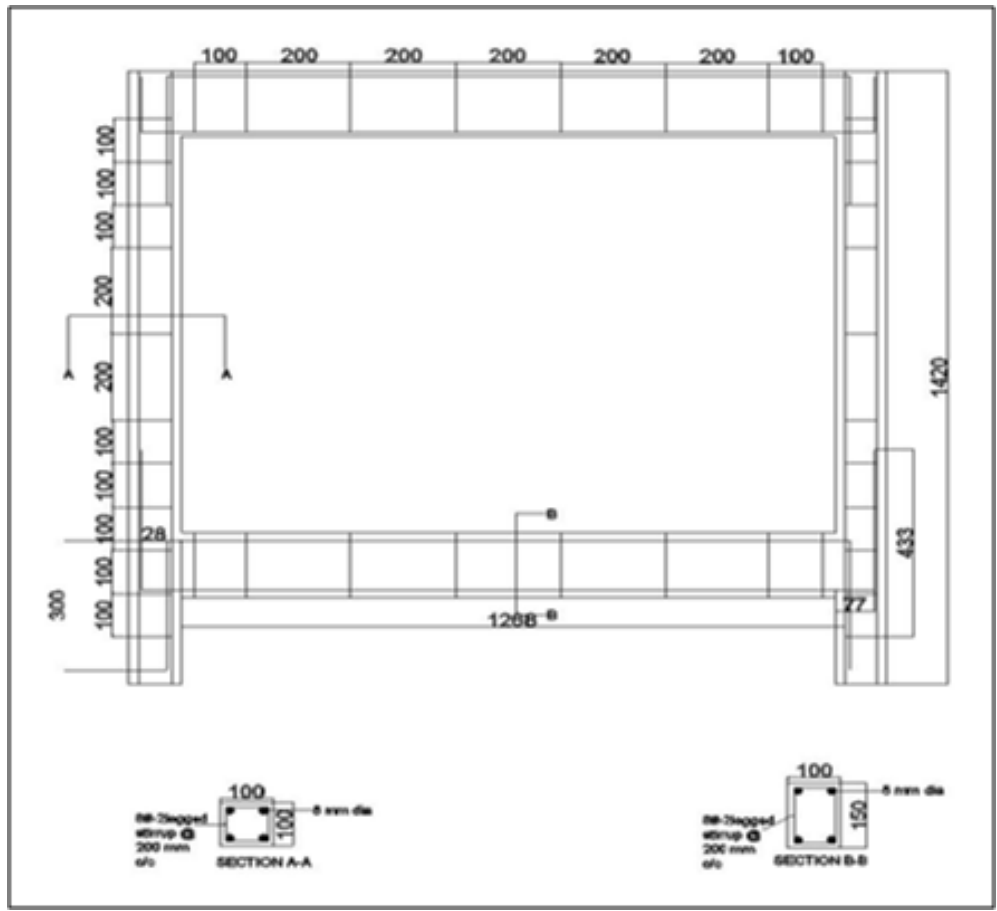

Figure 3: Reinforcement Detailing of RC Frame
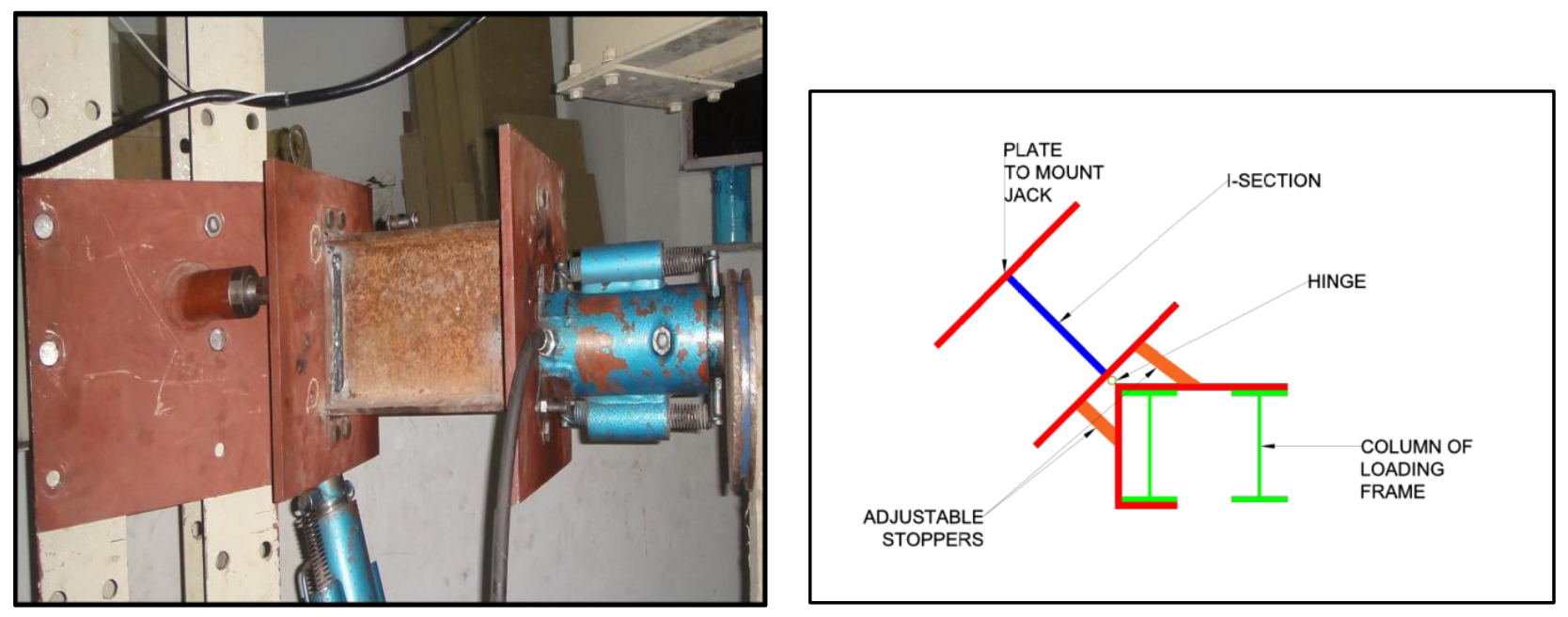

Figure 4: Lateral Load Mechanism 


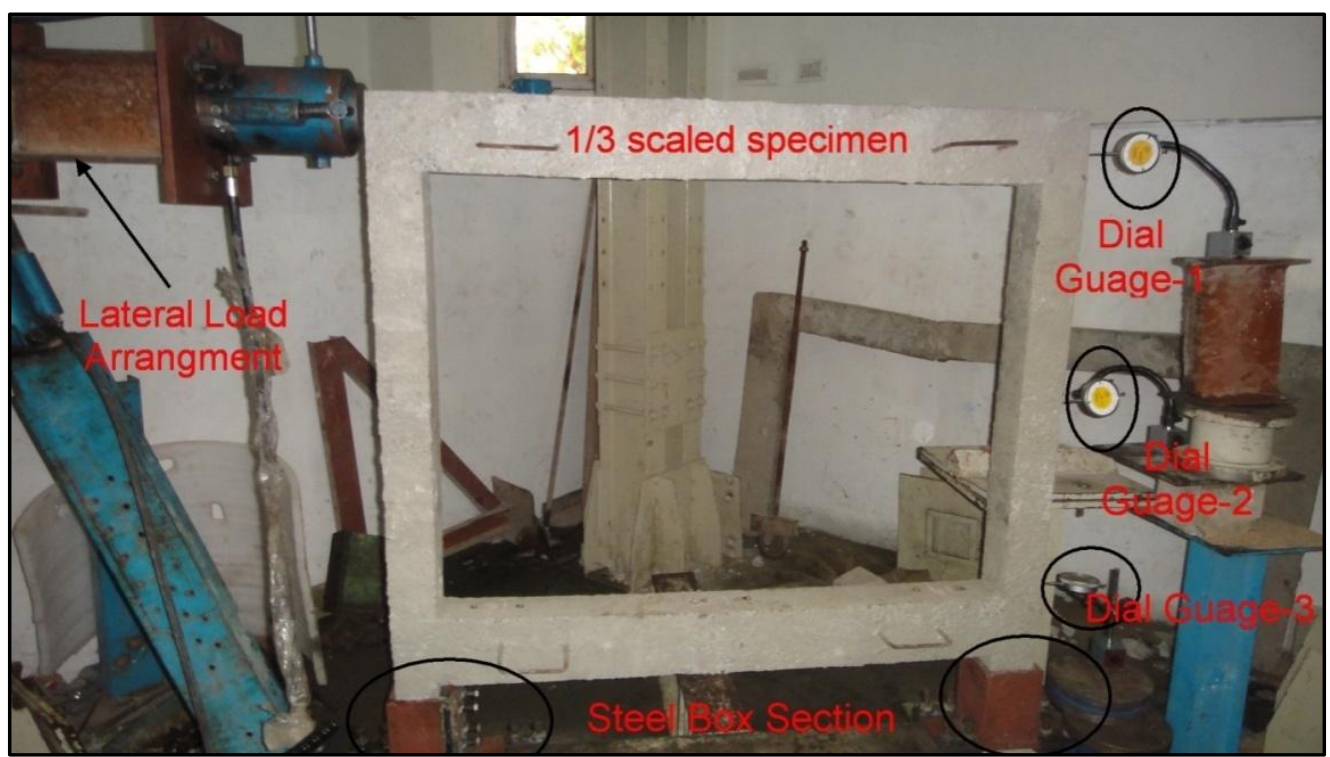

Figure 5: Test Set-up

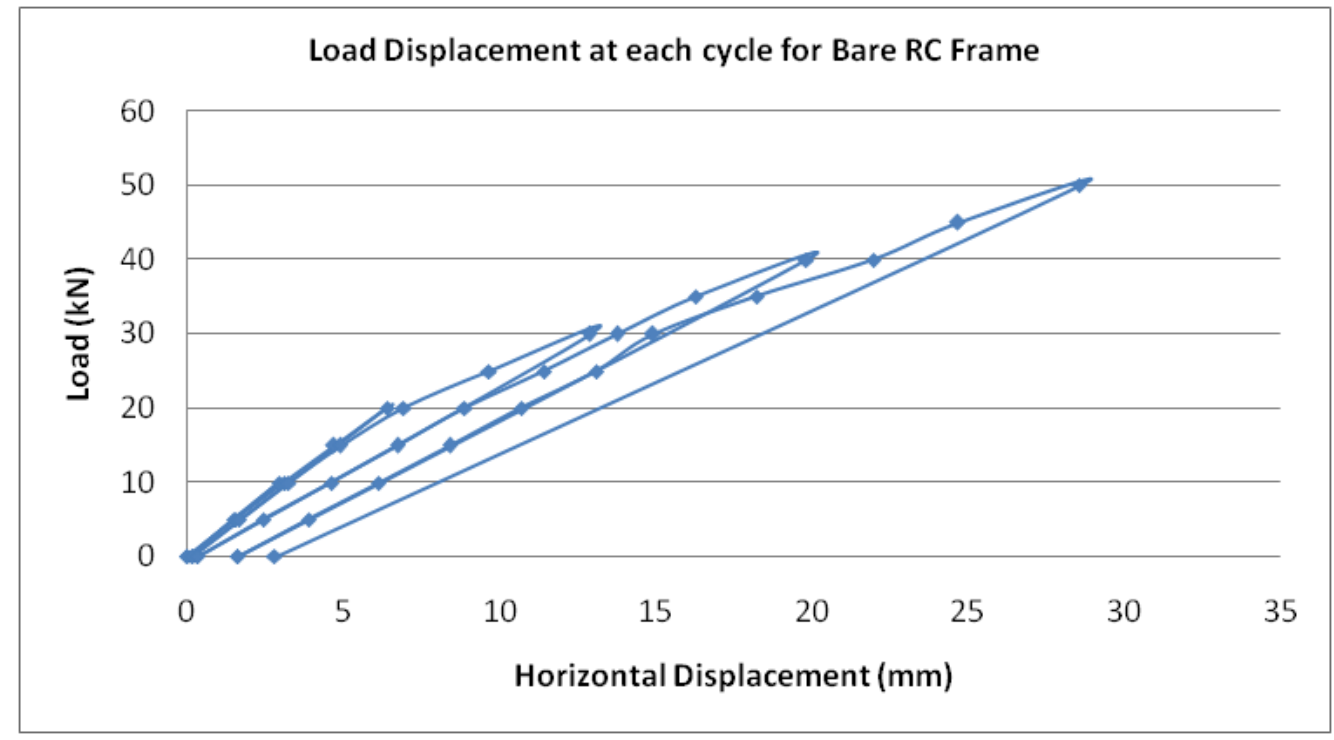

Figure 6: Load-Displacement at each loading/unloading cycle for Bare RC Frame 


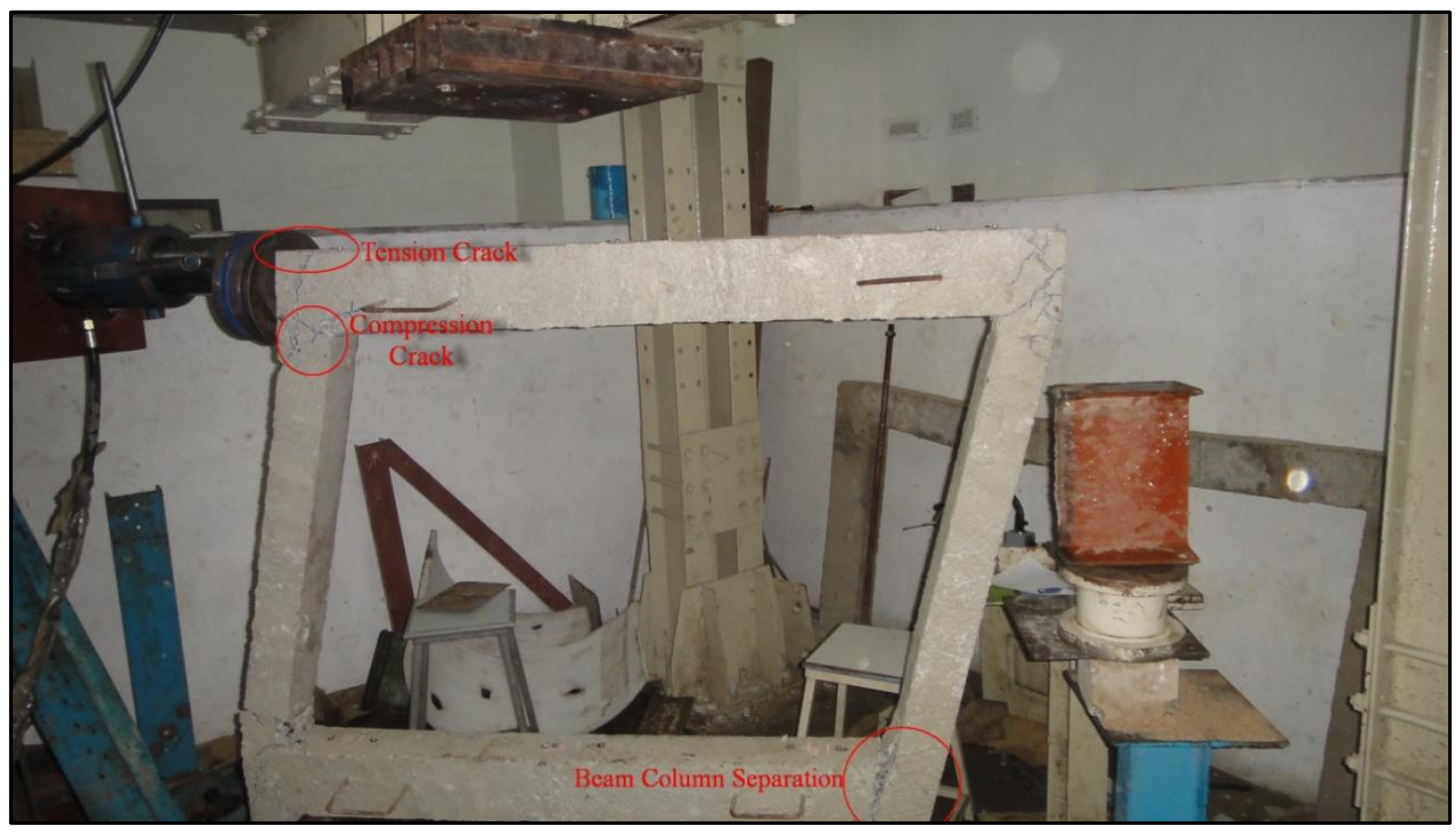

Figure 7: Failure in bare RC Frame

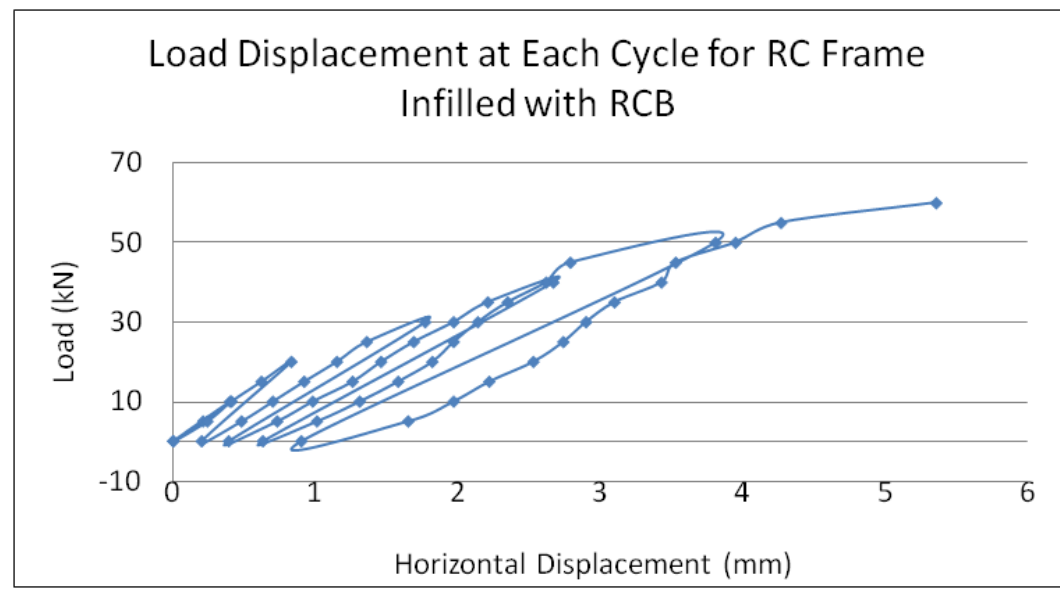

Figure 8: Load-Displacement at each loading/unloading cycle for RC Frame infilled with RCB

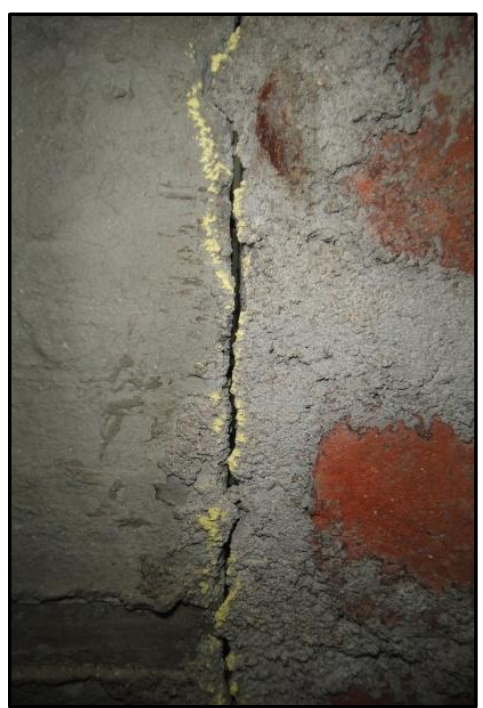

(A) Separation of mortar bond at column face

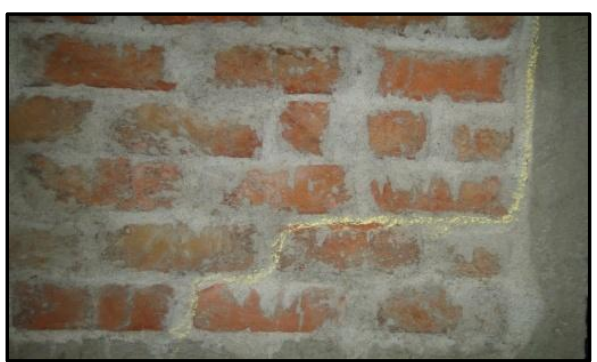

(B) Stepped type of failure

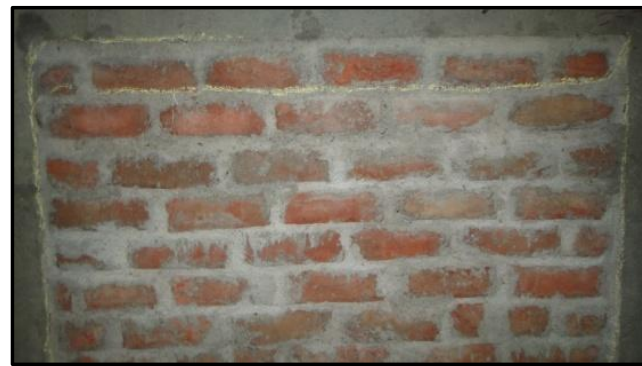

(C) Failure of horizontal mortar joint.

Figure 9: Failure of RC Frame infilled with RCB 


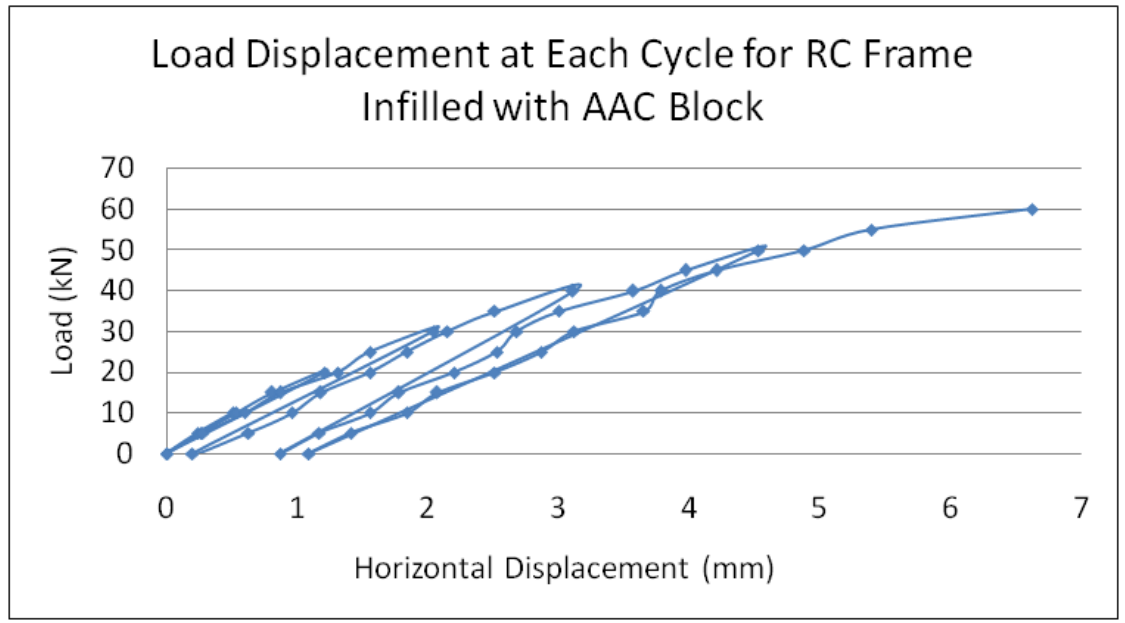

Figure 10: Load-Displacement at each loading/unloading cycle for RC Frame infilled with AAC Block

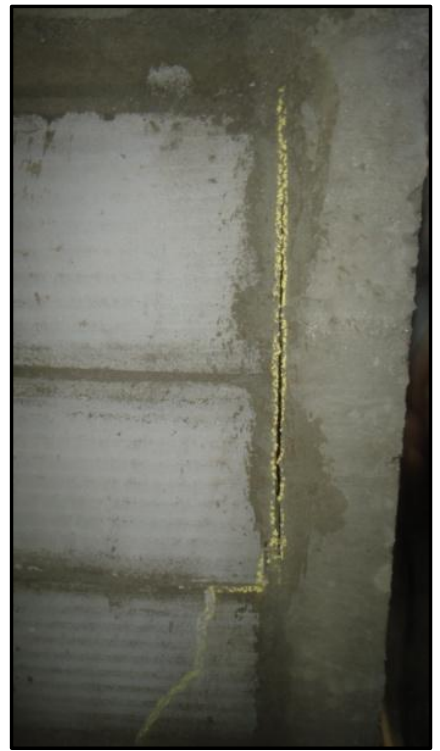

(A) Separation of mortar bond at column face

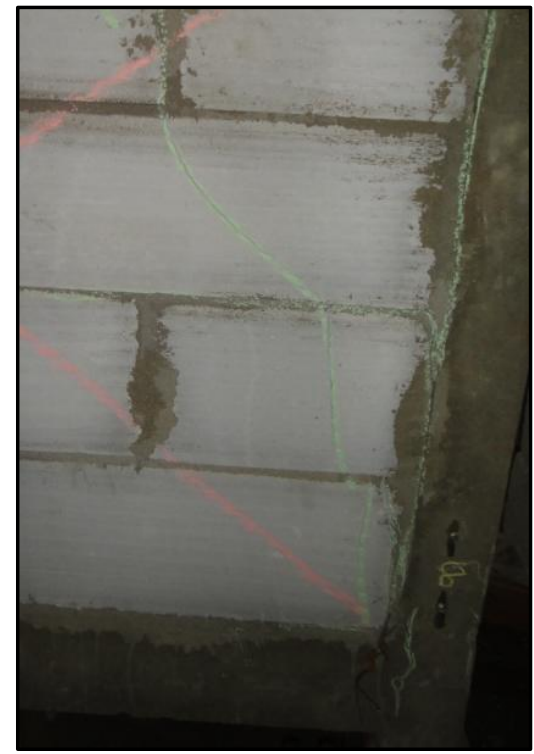

(B) AAC Block Failure

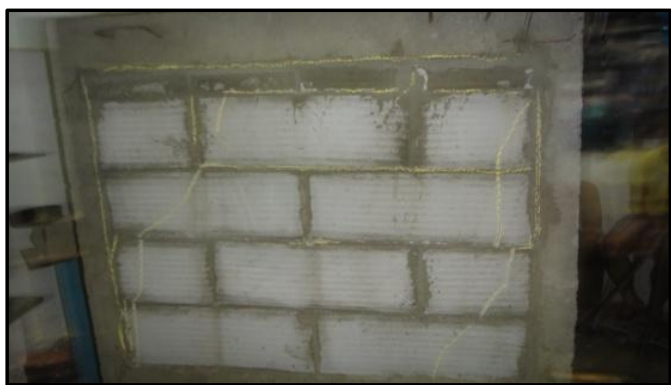

(C) Failure of horizontal mortar joint.

Figure 11: Failure of RC Frame infilled with AAC Block

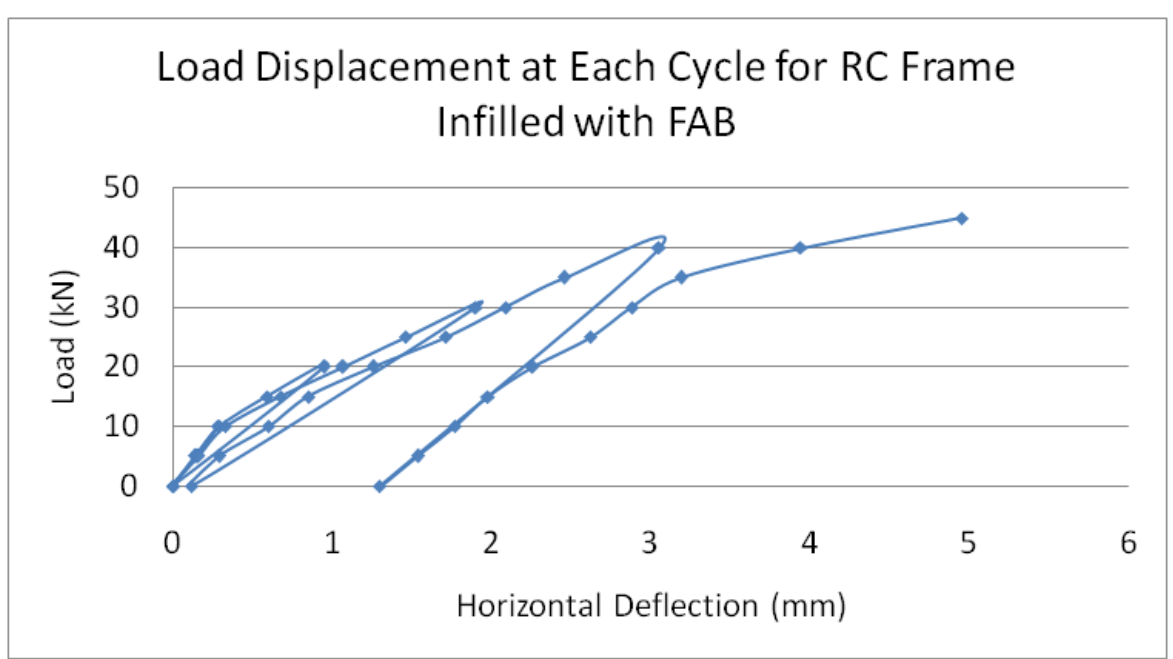

Figure 12: Load-Displacement at each loading/unloading cycle for RC Frame infilled with AAC Block 


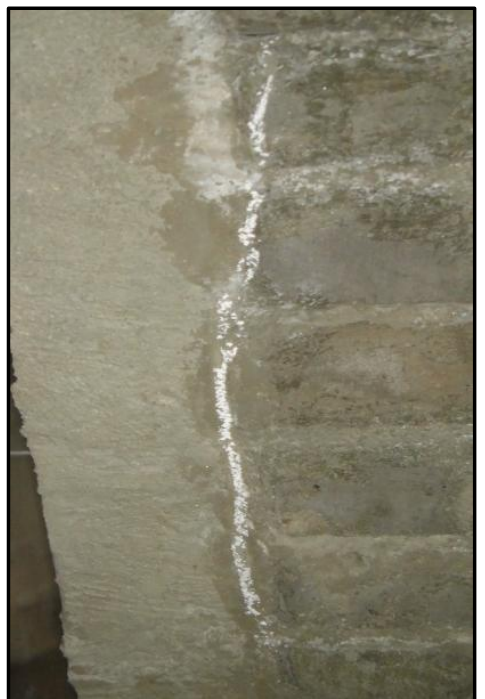

(A) Separation of Mortar Bond at Column Face

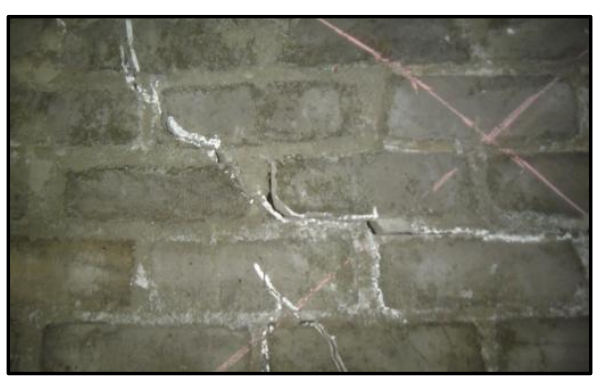

(B) Stepped Failure

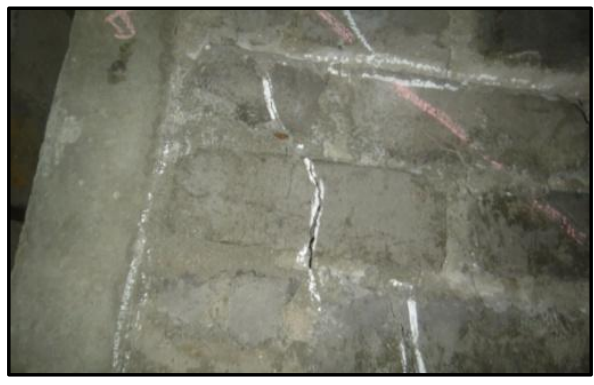

(C) Crushing of FAB

Figure 13: Failure of RC Frame infilled with FAB 